\title{
Foot rot and other foot diseases of goat and sheep in the semiarid region of northeastern Brazil ${ }^{1}$
}

\author{
Gildeni M.N. Aguiar², Sara V.D. Simões ${ }^{2}$, Tatiane R. Silva ${ }^{3}$, Adriana C.O. Assis², \\ João M.A. Medeiros ${ }^{2}$, Felício Garino $\mathrm{Jr}^{2}$ and Franklin Riet-Correa ${ }^{2^{*}}$
}

\begin{abstract}
Aguiar G.M.N., Simões S.V.D., Silva T.R., Assis A.C.O., Medeiros J.M.A., Garino Jr F. \& Riet-Correa F. 2011. Foot rot and other foot diseases of goat and sheep in the semiarid region of northeastern Brazil. Pesquisa Veterinária Brasileira 31(10):879-884. Hospital Veterinário, Universidade Federal de Campina Grande, Patos, PB 58700-000, Brazil. E-mail: franklin.riet@pq.cnpq.br

This paper reports the occurrence and epidemiology of outbreaks of foot rot and other foot diseases in goats and sheep in the semiarid region of Paraíba, northeastern Brazil. Four farms were inspected for the presence of foot lesion in sheep and goats and for environmental conditions, general hygiene, pastures, and disease control measures. The prevalence of foot lesions was $19.41 \%(170 / 876)$ in sheep and $17.99 \%(52 / 289)$ in goats, ranging between $5.77 \%$ and $33.85 \%$ in different farms. Foot rot was the most common disease, affecting $12.1 \%$ of the animals examined (141/1165), but with significantly higher $(\mathrm{p}<0.05)$ prevalence in sheep $(13.69 \%)$ than in goats $(7.27 \%)$. The frequency of malignant foot rot was also significantly lower $(p<0.05)$ in goats $(9.53 \%)$ than in the sheep $(40.83 \%)$. On one farm, Dorper sheep showed significantly higher $(\mathrm{p}<0.05)$ prevalence of foot rot $(17.5 \%)$ than Santa Inês sheep (6.79\%), and the number of digits affected was also higher in the former. Dichelobacter nodosus and Fusobacterium necrophorum were isolated from cases of foot rot. White line disease was found in 3.95\% of the animals, sole ulcers in $1.29 \%$, foot abscess in $1.03 \%$ and hoof overgrowth in $0.5 \%$. The high rainfall at the time of occurrence, grazing in wetlands, clay soils with poor drainage, presence of numerous stony grounds, closure of the flocks in pens at night, and introduction of affected animals were considered predisposing factors for the occurrence of foot diseases.
\end{abstract}

INDEX TERMS: Foot lesions, foot rot, foot abscess, small ruminants.

RESUMO.- [Pododermatite infecciosa e outras doenças podais de caprinos e ovinos no semiárido Nordestino.] Este trabalho relata a ocorrência e aspectos epidemiológicos de surtos de pododermatite infecciosa e outras afecções podais em caprinos e ovinos no semiárido paraibano. As propriedades foram inspecionadas quanto à presença de problemas podais e aspectos relacionados às condições ambientais, higiene, locais de pastejo e medidas de controle utilizadas. Nos ovinos a prevalência de lesões po-

\footnotetext{
${ }^{1}$ Received on June 27, 2011.

Accepted for publication on July 15, 2001

${ }^{2}$ Hospital Veterinário, Centro de Saúde e Tecnologia Rural (CSTR), Universidade Federal de Campina Grande (UFCG), Patos, PB 587000-00, Brazil. *Corresponding author: franklin.riet@pq.cnpq.br

${ }^{3}$ Programa de Pós-Graduação em Ciências Veterinárias, Universidade Federal Rural de Pernambuco (UFRPE), Rua Dom Manoel de Medeiros s/n, Dois Irmãos, Recife, PE 52171-900, Brazil.
}

dais foi de 19,41\% (170/876) e nos caprinos de 17,99\% (52/289), variando entre $5,77 \%$ e $33,85 \%$ nas diferentes propriedades. A pododermatite infecciosa foi a doença mais frequente acometendo $12,1 \%$ dos animais examinados (141/1165), sendo a prevalência nos ovinos (13,69\%) significativamente maior $(\mathrm{p}<0,05)$ do que a nos caprinos $(7,27 \%)$. A frequência de lesões malignas desta doença em caprinos $(9,53 \%)$ foi, também, significativamente menor $(p<0,05)$ do que nos ovinos $(40,83 \%)$. Em uma das propriedades a prevalência de pododermatite infecciosa entre os ovinos Dorper $(17,5 \%)$ foi significativamente maior do que a nos ovinos da raça Santa Inês (6,79\%), tendo os animais da primeira raça maior número de membros acometidos pela pododermatite infecciosa. Dichelobacter nodosus e Fusobacterium necrophorum foram isolados de casos de pododermatite infecciosa. A doença da linha branca foi constatada em 3,95\% dos animais, a úlcera de sola em 1,29\%, o 
abscesso do pé em 1,03\%, e crescimento excessivo do casco em $0,5 \%$. Os altos índices pluviométricos na época de ocorrência, o pastejo em áreas úmidas, os solos argilosos com pouca drenagem, os terrenos pedregosos, o encerramento em currais durante a noite e a introdução de animais doentes foram considerados fatores predisponentes para a ocorrência dos surtos.

TERMOS DE INDEXAÇÃO: Lesões podais, pododermatite infecciosa, pequenos ruminantes

\section{INTRODUCTION}

Foot diseases are major causes of lameness in small ruminants and responsible for great economic losses, due to reduced forage intake, less body weight gains and milk production, decreased reproduction rates, and premature culling of animals (Tadich \& Hernández 2000, Pugh 2004).

Foot rot is one of the most frequent foot diseases in goat and sheep (Kaler \& Green 2008). The primary agent of the disease is Dichelobacter nodosus; however, for the occurrence of infection should exist a synergistic action with Fusobacterium necrophorum. The latter bacterium is a natural inhabitant of soil and feces. It causes an interdigital dermatitis that allows invasion by $D$. nodosus (Wani \& Samanta 2005). D. nodosus is an obligate bacterium of ruminant digit and cannot survive longer than seven days in the environment (Green \& George 2008). Feet exposure for extended periods at ambient and wet pasture, feces and urine predisposes to infection and disease transmission between animals (Egerton 2002).

There are variations in the severity of foot rot, depending on the virulence factors of the $D$. nodosus strain $(\mathrm{Ab}-$ bott \& Egerton 2003). Benign strains of $D$. nodosus cause inflammation of the interdigital skin without separation of the corneal tissue; so it is impossible to differentiate clinically from interdigital dermatitis caused solely by $F$. necrophorum. Benign foot rot regress spontaneously in most affected animals when the environment becomes dry (Green \& George 2008). Malignant foot rot is characterized clinically by separation of corneal tissue and deeper parts of the hoof (underrunning). In this latter case virulent strains produce proteases allowing the degradation of corneal tissue of the digit (Billington et al. 1996). Nevertheless, other factors including animal resistance and environmental conditions are also important in the occurrence of benign or malignant foot rot (Abbott \& Egerton 2003).

Most studies of foot rot involve sheep, but goat can also be infected and there is transmission between sheep and goats (Ghimire et al. 1999).The lesions in goats are less severe than sheep, but may result in significant lameness (Pugh 2004).

Other diseases can cause lameness in small ruminants. The impaction of the interdigital space with feces, mud, and grass may cause a loss of skin integrity allowing invasion by F. necrophorum causing interdigital dermatitis (Winter 2008). Deeper lesions may involve a purulent infection with a foot abscess at the distal interphalangeal joint due to Archanobacterium pyogenes or other piogenic bacteria causing foot abscess (Riet-Correa 2007). A mild to severe lameness can be caused by white line disease, which is characterized by the separation of the corneal tissue in the abaxial solar surface region of the hoof as a result of dirt accumulation (Riet-Correa 1987).

In Brazil, outbreaks of foot rot are frequent in wooled sheep in the Southern region (Ribeiro 2007). However, there are few reports in hair sheep (Cavalcanti et al. 2004, Rodrigues et al. 2001) and goats. There are few reports of foot diseases of sheep and goats in the semiarid Northeastern region, but according to Pinheiro et al. (2000) foot rot occurs in about $67 \%$ of farms in the state Ceará. Although known to most farmers there is a great lack of information on important aspects of foot diseases in northeastern Brazil, including differential diagnosis, environmental changes associated with outbreaks, resistance or susceptibility of sheep and goat breeds raised in the region, and effective measures of control and prophylaxis. This study aimed to know the epidemiology and clinical aspects of outbreaks of foot rot and other foot diseases in goats and sheep in the semiarid of the state of Paraiba. With the knowledge obtained it will be possible to determine control and prophylactic measure.

\section{MATERIALS AND METHODS}

The study was conducted on four farms, located in the municipalities of Quixaba, São José das Espinharas, Patos, and Paulista, in the semiarid region of Paraiba, from March to September 2009. On all farms management was semi-intensive, with animals of different ages and different productive purposes (meat, milk and reproduction). The farms were inspected for the presence of predisposing factors for foot diseases, and to evaluate aspects related to hygiene, pasture, and the treatment and control measures used.

Data regarding the rainfall during January to December 2009 in region were obtained according to information from the Executive Agency for Water Management in Paraiba (AESA 2009), while normal rainfall, from 1961 to 1990, were extracted from Brasil (1992).

At all 1165 animals were observed on the four properties. The hooves were cleaned and trimmed for better observation and recording of lesions. Direct smears were performed with samples of the interdigital skin of some animals and stained by the Gram stain. From the same lesions were collected swabs, which were placed, immediately after collection, into tubes containing $10 \mathrm{~mL}$ of thioglycollate broth enriched with $0.5 \%$ ground sheep hoof. The tubes were sealed with 1-2mL sterile mineral oil and sent refrigerated to the Microbiology Laboratory. They were incubated in a microbial incubator at $37^{\circ} \mathrm{C}$ for $24-48$ hours. In the tubes of samples from Farm 1 and 2 bacteria were identified from the microbial growth observed in the tubes, through Gram stain. The broth culture from samples collected from Farm 2 and 3 were inoculated on plates containing modified agar hoof medium modified (Oslon et al. 1998), which consisted of $5 \%$ agar $^{4}, 0.5 \%$ beef extract ${ }^{4}, 1 \%$ Peptone $^{4}, 0.1 \%$ yeast extract ${ }^{4}$, $0.5 \%$ sodium chloride $\mathrm{e}^{5}$ and $0.5 \%$ ground sheep hoof. Then the plates were incubated anaerobically at $35 \pm 2{ }^{\circ} \mathrm{C}$ in anaerobic jars with an anaerobic system ${ }^{6}$ for five days. Dichelobacter nodosus and Fusobacterium necrophorum were identified by colony morphology (Thorley 1976) and morphotinctorial characteristics of the bacteria (Carter \& Chengappa 1991).

\footnotetext{
${ }^{4}$ Himedia ${ }^{\circledR}$ - Laboratories Pvt Ltd.

${ }^{5}$ Vetec ${ }^{\circledR}$.

${ }^{6}$ Probac do Brasil@.
} 
Prevalence data from different species and breeds on the same farms were analyzed statistically using the chi square test. On Farm 1 date from goats of the Saanen and Alpine breeds were not taken into account, because they have been recently introduced into the farm.

\section{RESULTS}

Of the 1165 animals examined in the four flock, 222 $(19.05 \%)$ had foot lesions. Mean prevalence was $17.13 \%$, $33.85 \%, 5.77 \%$ and $23.68 \%$, on Farm 1, 2, 3 and 4, respec- tively (Table 1 ). In the sheep the prevalence of foot lesions was $19.41 \%$ (170/876) and in goats was $17.99 \%(52 / 289)$.

The animals showed different foot diseases, including foot rot (Figs.1A,B), foot abscess (Fig.2A), white line disease (Fig.2B) and overgrowth of the hoof. The frequency of each condition is found in Table 2 . The foot rot was the most common disease, affecting $12.1 \%$ of the animals examined (141/1165). The prevalence in sheep (13.69\%) was significantly higher $(\mathrm{p}<0.05)$ than in goats $(7.27 \%)$. The frequency of malignant foot rot in goats $(9.53 \%$ of all le-

Table 1. Prevalence of foot lesions in different breeds of goats and sheep, observed between March and September 2009 on four farms of semiarid Paraiba

\begin{tabular}{|c|c|c|c|c|c|}
\hline Breed & $\begin{array}{c}\text { Farm } 1 \\
\%(\mathrm{~A} / \mathrm{H})\end{array}$ & $\begin{array}{c}\text { Farm } 2 \\
\%(\mathrm{~A} / \mathrm{H})\end{array}$ & $\begin{array}{c}\text { Farm } 3 \\
\%(\mathrm{~A} / \mathrm{H})\end{array}$ & $\begin{array}{c}\text { Farm } 4 \\
\%(\mathrm{~A} / \mathrm{H})\end{array}$ & $\begin{array}{c}\text { Total } \\
\%(\mathrm{~A} / \mathrm{H})^{\mathrm{a}}\end{array}$ \\
\hline Sheep & & & & & \\
\hline Sta Inês & $12,01(46 / 383)$ & $34,9(67 / 192)$ & - & - & $19,65(113 / 575)$ \\
\hline Dorper & $35(28 / 80)$ & $26,79(15 / 56)$ & $5,77(9 / 156)$ & - & $17,80(52 / 292)$ \\
\hline $\begin{array}{c}\text { Fat-Tailed Sheep } \\
\text { Goats }\end{array}$ & - & $55,5(5 / 9)$ & - & - & $55,5(5 / 9)$ \\
\hline Boer & $63,33(19 / 30)$ & - & - & $23,68(9 / 38)$ & $41,18(28 / 68)$ \\
\hline Savana & $23,33(7 / 30)$ & - & - & - & $23,33(7 / 30)$ \\
\hline Saanen & $7,8(11 / 141)$ & - & - & - & $7,8(11 / 141)$ \\
\hline Anglo-Nubian & $50(2 / 4)$ & - & - & - & $50(2 / 4)$ \\
\hline British Alpine & $25(2 / 8)$ & - & - & - & $25(2 / 8)$ \\
\hline Crosbreeds & $28,57(2 / 7)$ & - & - & - & $28,57(2 / 7)$ \\
\hline Brown Alpine & $0(0 / 31)$ & - & - & - & $0(0 / 31)$ \\
\hline Total & $17,13(117 / 714)$ & $33,85(87 / 257)$ & $5,77(9 / 156)$ & $23,68(9 / 38)$ & $19,05(222 / 1165)$ \\
\hline
\end{tabular}
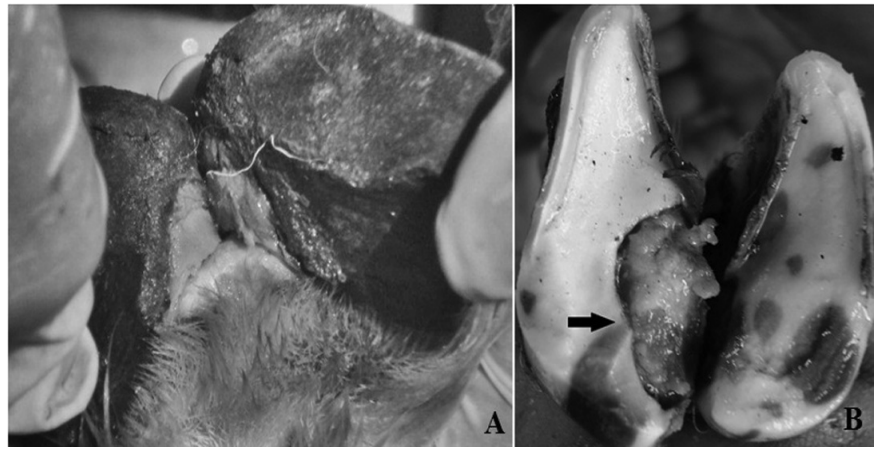

Fig.1. (A). Foot rot. Sheep. Interdigital dermatitis with hair loss and erosion of the interdigital skin. (B) Goat. Interdigital dermatitis with underrunning in the region of the heel (arrow).

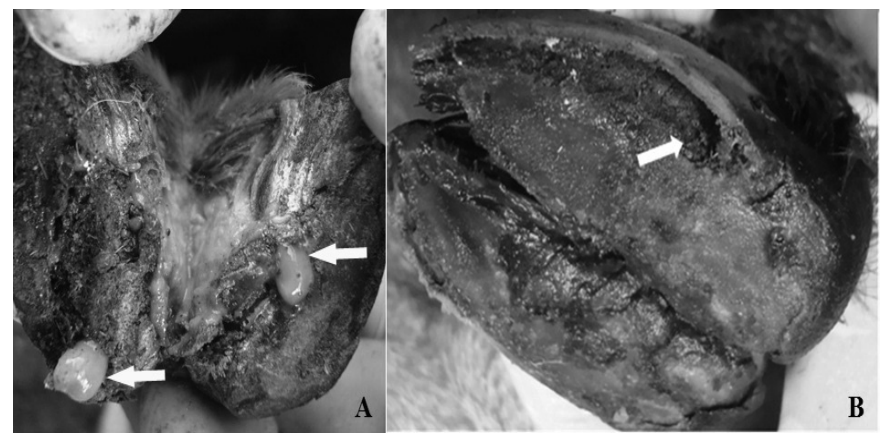

Fig. 2. (A) Foot abscess. Goat. There is pus draining from hoof (arrows). (B) White line disease. Sheep. The abaxial portion of the wall is separated from the sole, with accumulation of organic substance in the cavity (arrow). sions) was also significantly lower $(\mathrm{p}<0.05)$ than in sheep (40.83\%). On Farm 1, the prevalence of foot rot in Dorper sheep $(17.5 \%)$ was significantly higher than in Santa Inês sheep (6.78\%), and Dorper sheep had more feet affected than Santa Inês. Some of the animals with malignant foot rot also had proliferative granulomatous lesions of the interdigital skin and/or sole (Fig.3A); others had ulceration of the sole, which had become separated from horn (Fig.3B). Granulomatous lesions or sole ulcers, not associated with foot rot, were rare, except on Farm 1 where 15 (1.29\%) animals, 11 goats and four sheep without infectious foot rot, had sole ulcers (Table 2). Another disease found was foot abscess, which was observed with or without interdigital dermatitis caused by foot rot. The prevalence of foot abscess was $3.8 \%$ in goats and $1.41 \%$ in sheep. The disease affected the hind limbs in $66.67 \%$ of the goat cases and in $60 \%$ of the sheep cases.

In the four farms the sheep and goats grazed on natural pasture and stayed overnight in pens, except for the Fat Tailed Sheep on Farm 2, that were raised under extensive management practices. Farm 1 had a paddock of irrigated Cynodon dactylon (Tifton). On the four farms stony ground and wet areas in the borders of creeks or dams were found. The average area available for grazing animals varied: 500 ha on Farm 1, 50 ha on Farm 2, 25 ha on Farm 3, and 120 ha on Farm 4.

On Farm 1, numerous stones, moisture and excessive amounts of feces were found in the corrals. On Farm 2, the corral had low incidence of sunlight and poor hygienic 
Table 2. Foot lesions observed in four farms in goats and sheep in the semiarid Paraiba from March to September 2009

\begin{tabular}{|c|c|c|c|c|c|c|c|c|}
\hline \multirow[t]{2}{*}{ Type of lesions } & \multicolumn{3}{|c|}{ Goats } & \multicolumn{4}{|c|}{ Sheep } & \multirow[t]{2}{*}{ Total } \\
\hline & $\mathrm{F}^{\mathrm{a}} 1$ & F4 & Total & F1 & F2 & F3 & Total & \\
\hline Foot rot & 15 & 6 & 21 & 40 & 73 & 7 & 120 & 141 \\
\hline ID & 11 & 2 & 13 & 31 & 30 & 7 & 68 & 81 \\
\hline $\mathrm{ID}^{\mathrm{b}}+$ abscess & 2 & 4 & 6 & 1 & 2 & 0 & 3 & 9 \\
\hline $\mathrm{ID}^{\mathrm{b}}+$ underrunning & 2 & 0 & 2 & 8 & 41 & 0 & 49 & 51 \\
\hline Toe granuloma & 1 & 0 & 1 & 0 & 0 & 0 & 0 & 1 \\
\hline Foot abscess & 3 & 2 & 5 & 2 & 3 & 2 & 7 & 12 \\
\hline White line disease & 13 & 0 & 13 & 27 & 6 & 0 & 33 & 46 \\
\hline Ulcers & 10 & 1 & 11 & 4 & 0 & 0 & 4 & 15 \\
\hline Excessive growth of the hoof & 1 & 0 & 1 & 1 & 4 & 0 & 5 & 6 \\
\hline Defect on limb conformation & 0 & 0 & 0 & 0 & 1 & 0 & 4 & 1 \\
\hline Total with foot lesions & 43 & 9 & 52 & 74 & 87 & 9 & 170 & 222 \\
\hline Total with healthy foots & 251 & 38 & 289 & 463 & 257 & 156 & 876 & 1165 \\
\hline
\end{tabular}

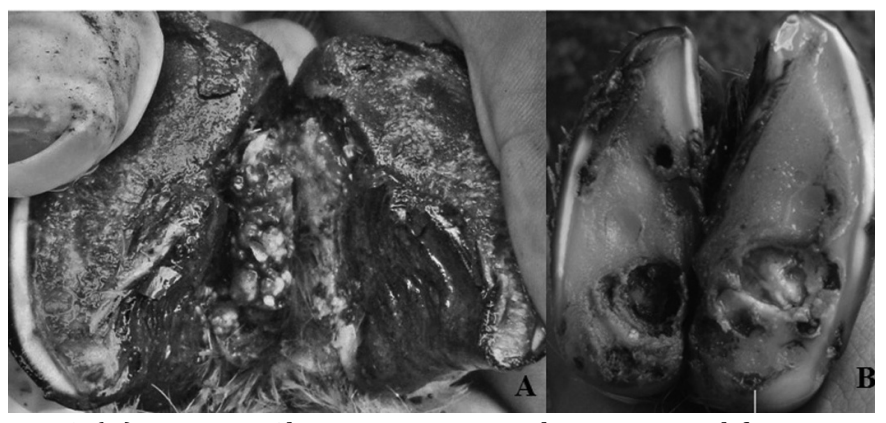

Fig. 3 (A) Foot rot. Sheep. Tissue granulomatous proliferation is observed in the interdigital region. (B) Sole ulcers. Goat. Ulcerated lesions are seen in the sole and heel.

conditions with excessive amount of feces. On Farm 3, the outbreak was associated with the introduction of animals with foot problems. On Farm 1, 2 and 4 the farmers reported foot disease outbreaks in previous years.

During previous outbreaks of foot diseases on the farms, inappropriate treatments were performed including use of formalin or copper sulphate mixed with formalin at inappropriate concentrations and frequency, antibiotic under-dosing, or the use of repellents as the only form of treatment. Preventive measures such as periodic foot trimming and preventive foot-bathing had never been adopted on any Farm. On Farm 2 foot trimming in sheep was conducted at the moment of occurrence of outbreaks, but without adequate treatment.

The frequency of rainfall in 2009 was higher when compared to normal rainfall in the region (Fig.4).

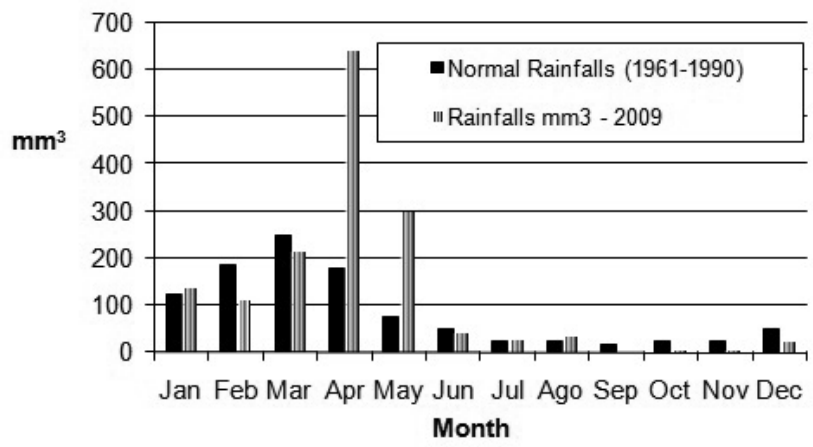

Fig.4. Monthly precipitation in 2009 and normal rainfall (1961-1990) for the semiarid region of Paraíba. Source: Brasil 1992; AESA 2009.
Gram negative rods with terminal enlargements, characteristic of Dichelobacter nodosus, were observed in examination of direct smears of the lesions and in smears of the microbial growth in broth cultures. Also Gram-negative rods of variable length with beaded filaments, characteristic of Fusobacterium necrophorum, were observed. In the anaerobic cultures in hoof medium grayish-white, opaque, colonies with irregular edges and elevated center were observed. The smears of the colonies revealed Gram-negative bacteria with the characteristics of $D$. nodosus.

\section{DISCUSSION}

The high prevalence of foot rot on the four farms studied indicates the importance of the disease in the semiarid region of Brazil, when there are favorable conditions to the transmission of the disease. The favorable environmental conditions of the pastures during the rainy period, associated with the presence of excess moistures and feces in the corrals where the animals stay at night, are predisposing factors for foot rot transmission. Such conditions are also favorable for the occurrence of foot rot and white line disease. The moisture causes devitalization of the interdigital space allowing infection by Fusobacterium necrophorum and Dichelobacter nodosus (Graham \& Egerton 1968). Additionally, the feet are more susceptible to injury when the animals walk in areas with stones and scrub vegetation, which cause traumatic injuries, including sole ulcers, granuloma and white line disease.

In the semiarid region of Northeastern Brazil, conditions favoring foot rot transmission are observed during a short period of the year. The region is characterized by a warm climate with a mean temperature of $26^{\circ} \mathrm{C}$ and 500 $800 \mathrm{~mm}$ annual precipitation. The rains are irregular and in some years rainfall are insignificant or low. The rainy season is short, from January-February to April-May. The relative humidity is low, ranging from $60-75 \%$, and vegetation, named caatinga, is an exclusive Brazilian biome (AESA 2009). Another factor that may favor the occurrence of outbreaks of foot rot in 2009 was the higher rainfall (127.4 $\mathrm{mm}^{3}$ ) during this year in comparison with the mean rainfall (83.6mm) for the region (Fig.4).

The absence of correct control measures observed in the four farms is also an important factor for the transmission of the disease during the rainy season. The highest 
prevalence was found in Farm 2, in which after start of the outbreak the farmer performed hoof trimming without treatment. Hoof trimming performed without treatment facilitates the transmission of the disease (Wassink et al. 2003). The wrong treatment applied by farmers and the lack of preventive measures may have contributed to the occurrence of new cases. Also because of the spontaneous regression of cases of foot rot during the dry season, farmers lose interest in control measures and the disease becomes cyclic, recurring every rainy season.

Soil conditions should also be considered in outbreaks of foot rot. The soils of the area where the outbreaks occurred are eutrophic red abruptic argisols with medium textured and high clay content (Cavalcante et al. 2005). Clay soils allow water retention in the land and facilitate the occurrence of foot rot when compared to sandy soils with low clay content, which are capable of providing dry feet within two hours immediately after episodes of rainfall (Depiazzi et al. 1998).

The occurrence of severe forms of foot rot with underruning confirm that there are virulent strains of $D$. nodosus in the Brazilian semiarid region; however, in goats and sheep there was a higher frequency of interdigital dermatitis without underruning. The occurrence of benign or virulent forms depend on three factors: virulence of the agent; environmental conditions favorable for transmission; and host resistance (Graham \& Egerton 1968). The lower frequency of foot rot in goats than in sheep, as well as the smallest number of animals with virulent forms, represents the higher resistance of goats compared to sheep. According to Ghimire et al. (1999), sheep tend to have faster progression and more severe lesions caused by $D$. nodosus than goats, probably due to increased thickness of stratum corneum of the interdigital skin in relation to sheep.

There is no information on differences in susceptibility/ resistance between different breeds of hair sheep or when compared hair sheep with wolled breeds raised in areas with higher rainfall, as in southern Brazil, where foot rot is a disease much more frequent than in the semiarid region. In this study, the significantly higher prevalence observed in the Dorper sheep in relation to Santa Inês, on Farm 1, suggests a higher susceptibility of the former. On the other hand, Dorper sheep seems to be not highly susceptible, because in Farm 3 the animals of this breed showed only interdigital dermatitis, without underrunning. One feature observed in breeds with foot rot resistance is the largest number of animals with benign lesions (Emery et al. 1984). However, the absence of underrunning could also be due to the absence of virulent strains or better environmental conditions due to the periodic cleaning of the pens, a practice not held in the other farms.

The environmental conditions favorable to the development of infectious foot rot, were also important for the occurrence of foot abscess. Most cases of foot abscess were probably secondary to lesions caused by $F$. necrophorum and $D$. nodosus in the interdigital skin (Riet-Correa 1987). However, stony ground can produce traumatism in the coronary band of the feet followed by bacterial infection and foot abscess (Riet-Correa 2007).
To reduce the economic impact of foot rot in the semiarid region it is necessary the application of adequate control measures during outbreaks, including foot trimming, separation of affected from non affected animals, correct footbaths and use of clean paddocks after treatment, and culling of chronic cases. For the prevention or eradication of the disease these measures should be applied during dry season when clinical cases decrease significantly, also imported animals should be inspected to avoid the introduction of the disease.

\section{REFERENCES}

Abbott K.A. \& Egerton J.R. 2003. Effect of climatic region on the clinical expression of foot rot of lesser clinical severity (intermediate foot rot) in sheep. Aus. Vet. J. 81(12):756-762.

AESA 2009. Relatório de previsão climática da AESA. Avaliable from <http://www.aesa.pb.gov.br/relatorios/previsao/arquivos/previsao_ climatica_jan_mar_2009_AESA.pdf> Web site acess: July 24, 2009.

Billington S.J., Johnston J.L. \& Rood J.I. 1996. Virulence regions and virulence factors of the ovine foot rot pathogen, Dichelobacter nodosus. FEMS Microbiol. Lett. 145:147-156.

Brasil 1992. Normais Climatológicas: 1961-1990. Departamento Nacional de Meteorologia, Ministério da Agricultura e da Reforma Agrária, Brasília, DF. 84p.

Carter G.R. \& Chengappa M.M. 1991. Nonspore-forming anaerobic bactéria, p.145-149. In: Ibid. (Eds), Essentials of Veterinary Bacteriology and Mycology. $4^{\text {th }}$ ed. Lea and Febiger, Philadelphia.

Cavalcante F.S., Dantas J.S., Santos D. \& Campos M.C.C. 2005. Considerações sobre a utilização dos principais solos no Estado da Paraíba. Revta Cient. Eletrônica de Agronômia 8:1-10.

Cavalcanti A.S.R., Aguiar G.M.N. \& Ayres M.C.C. 2004. Frequência da pododermatite em ovinos criados na microrrgegião dos Tabuleiros Costeiros no Estado da Bahia. XXXI Congr. Bras. Med. Vet., São Luis, Maranhão. (Abstract)

Depiazzi L.J., Roberts W.D., Hawkins C.D., Palmer M.A., Pitman D.R., Mcquade N.C., Jelinek P.D., Devereaux D.J. \& Rippon R.J. 1998. Severity and persistence of foot rot in Merino sheep experimentally infected with a protease thermostable strain of Dichelobacter nodosus at five sites. Aust. Vet. J. 76(1):32-38.

Egerton J.R. 2002. Management of footrort in small ruminants. XII International Symposium on lameness in ruminant. Orlando-USA. (Eletronic Publishing)

Emery D.L., Stewart D.J. \& Clark B.L. 1984. The comparative susceptibility of five breeds of sheep to foot-rot. Aus. Vet. J. 61(3):85-88.

Ghimire S.C., Egerton J.R. \& Dhungyel O.P. 1999. Transmission of virulent foot rot between sheep and goats. Aus. Vet. J. 77(7):450-453.

Graham N.P.H. \& Egerton J.R. 1968. Pathogenesis of ovine foot rot: The role of some environmental factors. Aust. Vet. J. 44:235-240.

Green L E. \& George T.R.N. 2008. Assessment of current knowledge of foot rot in sheep with particular reference to Dichelobacter nodosus and implications for elimination or control estrategies for sheep in Great Britain. Vet. Journal 175:173-180.

Kaler J. \& Green L.E. 2008. Naming and recognition of six foot lesions of sheep using written and pictorial information: A study of 809 English sheep farmers. Prev. Vet. Med. 83(1):52-64.

Oslon M.E., Gard S.M., Gradin J. \& Morck D.W. 1998. Serological classification and virulence determination of Dichelobacter nodosus isolate from Alberta and British Columbia sheep. Can. J. Vet. Res. 62:33-37.

Pinheiro R.R., Gouveia A.M.G., Alves F.S.F. \& Haddad. J.P.A. 2000. Aspectos epidemiológicos da caprinocultura cearense. Arq. Bras. Med. Vet. Zootec. 52:534-543.

Pugh D.G. 2004. Enfermidades do Sistema Músculo Esquelético: Clínica de caprinos e ovinos. Roca, São Paulo, p.252-256. 
Ribeiro L.A.O. 2007. Foot rot dos ovinos, p.295-305. In: Riet-Correa F., Schild A.L., Lemos R.A.A. \& Borges J.R.J. (Eds), Doenças de Ruminantes e Equinos. Vol.1. 3a ed. Varela, São Paulo.

Riet-Correa F. 1987. Enfermedades Del aparato locomotor, p.219- 238. In: Marlan J.B., Campo A.D. \& Mari J.J. (Eds), Enfermedades de los Lanares. Vol.2. Hemisfério Sur, Montevideo.

Riet-Correa F. 2007. Abscesso de pé, p.199-201. In: Riet-Correa F., Schild A.L., Lemos R.A.A. \& Borges J.R.J. (Eds), Doenças de Ruminantes e Equinos. Vol.1. 3a ed. Varela, São Paulo.

Rodrigues C.A., Mendes L.C.N., Peiró J.R. \& Feitosa F.L.F. 2001. Ocorrência de um surto de "footrot" em um rebanho de ovinos na região de Araçatuba,SP, Brasil. Revta Educ. Contin. CRMV-SP 4(3):12-19.
Tadich N. \& Hernandez M. 2000. Prevalencia de lesions podales en ovinos de 25 exploraciones familiars de la provincia de Valdivia, Chile. Arch. Med. Vet. 32(1):63-74.

Thorley C.M.A. 1976. Simplified method for the isolation of Bacteroides nodosus from ovine foot-rot and studies on its colony morphology and serology. J. Appl. Bact. 40:301-309.

Wani S.A. \& Samanta I. 2005. Current understanding of the aetiology and laboratory diagnosis of foot rot. Vet. Journal 171:421-428.

Wassink G.J., Grogono-Thomas R., Moore L.J. \& Green L.E. 2003. Risk factors associated with the prevalence of foot rot in sheep from 1999 to 2000. Vet. Rec.152:351-358.

Winter A.C. 2008. Lameness in sheep. Small Rumin. Res.76:149-153. 